Tạp chí Khoa học và Công nghệ biển T12 (2012). Số 2. Tr 32 - 46

\title{
SOME NEW DATA ON PHYTOPLANKTON DISTRIBUTION IN THE WESTERN OF TONKIN GULF
}

\author{
CHU VAN THUOC, NGUYEN THI MINH HUYEN, PHAM THE THU \\ Institute of Marine Environment and Resources (IMER)
}

LE THANH TUNG

Research Institute for Marine Fisheries (RIMF)

\begin{abstract}
Summary: This paper presented some new data on phytoplankton community in western of Tonkin Gulf gained from two surveys conducted in October 2003 (dry season) and August 2004 (rainy season). The phytoplankton samples were collected at 21 stations in dry season and 32 stations in rainy season at different depths with interval between 10 and 20 meters depending on the certain stations, spreading in the whole western area of Tonkin Gulf. Among them, there were two temporal (day-night) stations in the first survey and three ones in the second one which were sampled every 3-4 hours. A total of 278 species belonging to 81 genera, 4 classes of microalgae had been recorded in the western of Tonkin Gulf with the majority belonging to diatoms (51 genera, 148 species occupied 53.2\%), then the dinoflagellates (28 genera, 125 species, 45\%). There were about 26 potentially harmful species which had been found in the studied area with the most diverse belonged to dinoflagellates such as Alexandrium (9 species), Dinophysis (5 species). The phytoplankton diversity index $\left(H^{\prime}\right)$ in the area ranged from 1.5 to 5.0 (dry season) and from 0.3 to 5.4 (rainy season). The total cell densities of phytoplankton varied horizontally and vertically. In generally, the cell density decreased from the coast to offshore and from the surface layers to the bottom ones, but inversely at the day-night sampling stations in the north-west coast of the Gulf. The density in rainy season was higher and fluctuated more strongly than those in dry season.
\end{abstract}

Key words: Tonkin Gulf, phytoplankton, harmful microalgae.

\section{INTRODUCTION}

The first survey on marine environment and resources in Tonkin Gulf had been carried out during 1960-1965 in the cooperation program between Viet Nam and China. Since then, there are several surveys that have only taken at some areas of the Gulf. The national project named "General survey on natural conditions, resources and environment 
of the Tonkin Gulf" (coded: KC09-17) had been carried from 2003 to 2005 in this area. During the implementation of project, a total of 41 stations spreading on the western side of the gulf belonging to territorial waters of Viet Nam were investigated. Two main cruises were conducted in October 2003 (dry season) and August 2004 (rainy season) by the research vessel named "Marine Research" of the Centre of Marine Meteo-hydrology (Ministry of Environment and Resources of Viet Nam). There were four main objects had been studied in Tonkin Gulf included marine meteo-hydrology, marine chemistry, marine biology, marine geology and geo-physic. Among the marine biology factors, the species composition and distribution of phytoplankton in Tonkin Gulf had been studied. This

paper presented the main study results on phytoplankton community obtained from two cruises in October 2003 and August 2004 in the Gulf belonging to branch project coded KC09-17.01 led by IMER.

\section{MATERIALS AND METHODS}

A total of 401 phytoplankton samples collected in Tonkin Gulf were analyzed. Among them, there were 145 samples (including 117 quantitative and 28 qualitative ones) collected at 21 stations in October 2003, and 256 samples (199 quantitative and 57 qualitative ones) collected at 32 stations in August 2004.

The phytoplankton samples were collected at 36 stations showed in the Fig. 1. The qualitative samples were collected by plankton net (mesh size $20 \mu \mathrm{m}$ ) by drawing slowly from the bottom to surface and the quantitative ones collected by Niskin bottle at several depths with interval from 10-15 m depending on the depth of stations. For each depth, 1L of sea water was sampled and preserved by natural Lugol's solution.

Identifying phytoplankton species has been undertaken under OLYMPUS BX-51 microscope. Using Calcoflour (MR2) to stain the dinoflagellates and then observe under fluorescence light. The morphological observation was used to identify species names based on the references such as: Abé (1967), Balech (1995), Fukuyo et al. (1990), Larsen et al. (1992), Larsen et al. (2004), Tomas (1997), Taylor (1976), Truong Ngoc An (1993).

Counting the cell density: An amount of $1 \mathrm{~mL}$ of sub-samples was taken from a 10 $\mathrm{mL}$ (or $20 \mathrm{~mL}$ ) sample vials, which had been condensed from $1 \mathrm{~L}$ of sea water, counted the number of cells of each species in the Sedgwick-Rafter chamber. 


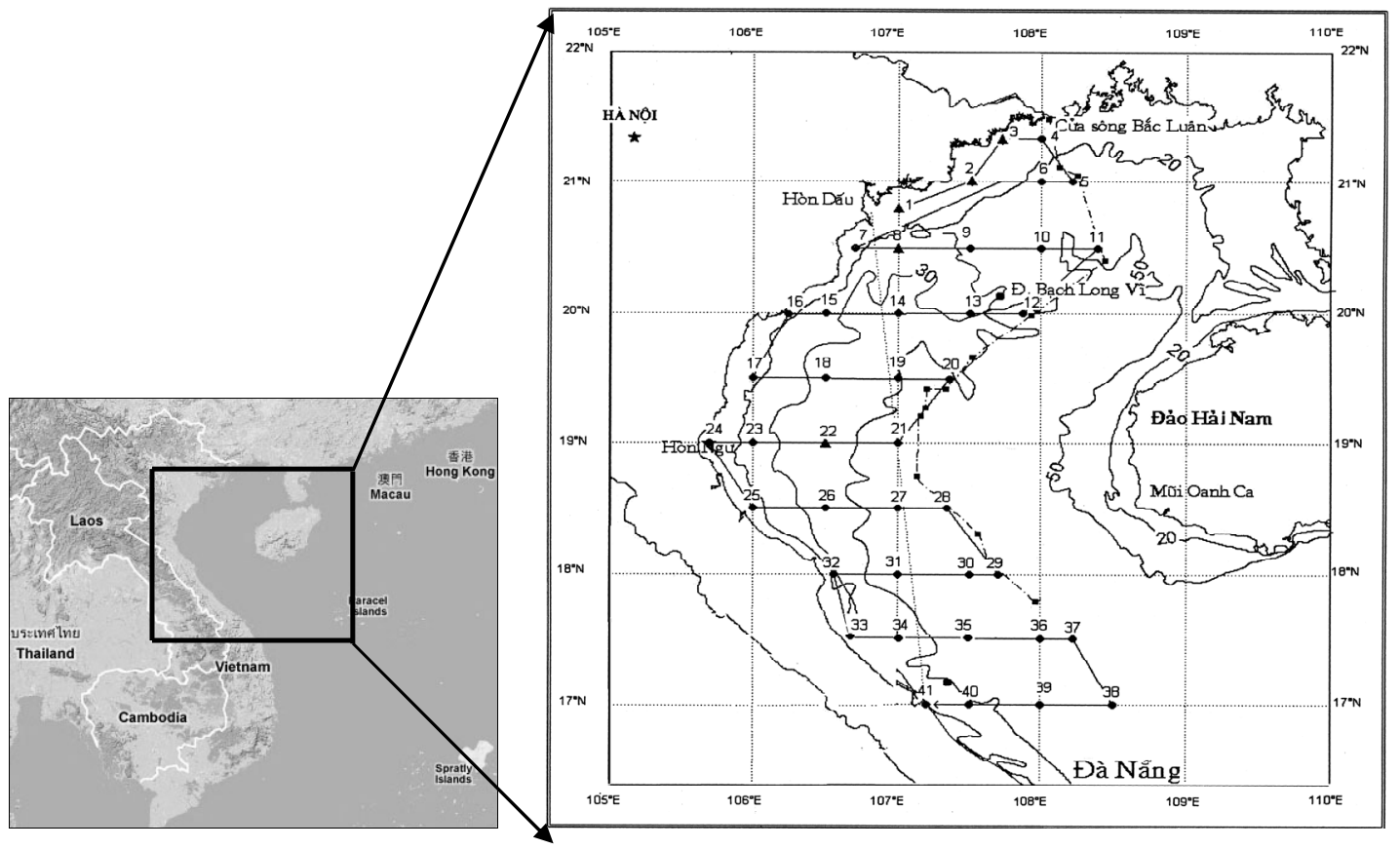

Figure 1: Location of sampling stations in Tonkin Gulf (October 2003\& August 2004)

- Spatial sampling stations $\boldsymbol{\Delta}$ Temporal (day-night) sampling stations

\section{RESULTS AND DISCUSSIONS}

\section{Environmental conditions}

The assessment results of water temperature in the Tonkin Gulf during 40 years showed that the highest temperature of surface water found in September with average values ranging from 29 to $31^{\circ} \mathrm{C}$, the lowest one found in February (ca. $18-20^{\circ} \mathrm{C}$ ). In generally, the temperature in Tonkin Gulf is rather homogeneous in spatial with the disparity ca. $1-3^{\circ} \mathrm{C}$. The temperature increased gradually from the north to south, and varied between the coastal and offshore areas about $1-2^{\circ} \mathrm{C}$ [9]. In August 2004, the lowest temperature $\left(24.5^{\circ} \mathrm{C}\right)$ recorded near the coast (station 6$)$ and the highest one $\left(27.7^{\circ} \mathrm{C}\right)$ was in the southern area (station 39 ). The temperature fluctuation by interval $10 \mathrm{~m}$ depth was less than $2^{\circ} \mathrm{C}$ (Fig. 2). 


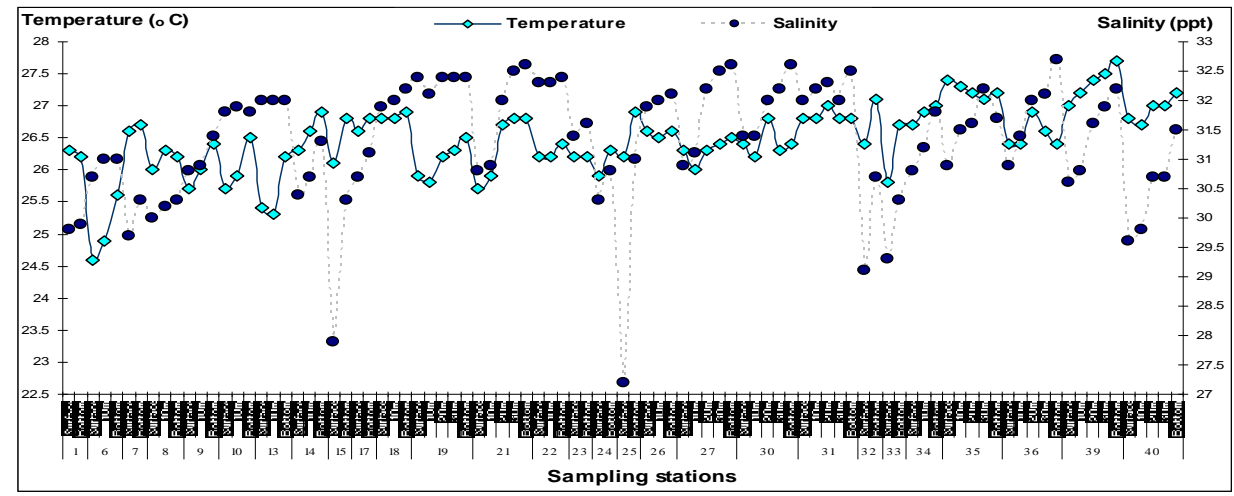

Figure 2: Temperature and salinity in the western of Tonkin Gulf during the survey in August 2004

The monthly disparity in salinity in the off-shore stations of Tonkin Gulf was ca. 1-2 ppt. The maximum values recorded in January (ca. 31-33 ppt) and minimum one found in August and September (24-26 ppt). The disparity in salinity in the coastal area was rather high, ca. 12-15 ppt. The maximum value was up to 27-28 ppt, and lowest one was about 57 ppt. It is obvious that the coastal waters of Tonkin Gulf had been affected strongly by season [9]. During August 2004, the lowest salinity value recorded in coastal area (surface layers of stations $25 \& 15$ ) and the highest was in the offshore (station 36) with values about 27-28 ppt and $32.7 \mathrm{ppt}$ respectively. The maximum disparity between surface and bottom layers was about 4 ppt found at station 15 (Fig.2).

\section{Diversity of phytoplankton in the western of Tonkin Gulf}

The analyzing results showed that a total of 278 species belonging to 81 genera, 4 classes of microalgae had been recorded in the studied area. Among them, the most diversity in species were belonged to diatoms- Bacillariophyceae (148 species, 51 genera, occupied $53.2 \%$ in total species), then the dinoflagellates- Dinophyceae included 125 species, 28 genera (45\%). Two remain classes (Cyanophyceae and Dictyochophyceae) occupied only $1.1 \%$ and $0.7 \%$ respectively (Fig. 3). The number of species found in this study is nearly equivalent to the results of Viet Nam-China joint survey in 1960 for the whole Tonkin Gulf, that reported a total of 279 species found including Bacillariophyta 191 species, Pyrrophyta 84 species, Cyanophyta 3 species and Silicoflagellata 1 species [15]. It is obvious that many dinoflagellates had not been recorded yet in the previous investigation. The number of diatoms in 1960 in the whole Tonkin Gulf was much more diversely due to monthly sampling in the larger scale while this study was only taken in October and August in the western area of the Gulf. Thus, many species of diatom presenting in different environment conditions had been recorded in 1960. However, the phytoplankton composition found in this study was much more diversely in comparing with some investigations such as the Viet Nam-Russia joint survey on fishery resources in 
Tonkin Gulf during 1960-1961, that recorded 142 sps. in total, including 112 species of diatoms and 30 species of dinoflagellates found [8]. The monthly survey at the Hai PhongQuang Ninh coastal waters carried out during 1971-1972 with 186 species, 61 genera (including 156 species, 50 genera of diatoms; 28 species, 9 genera of dinoflagellates and 2 genera of cyanobacteria and chlorophytes) were recorded [13]. The above results have proved that diatoms were the most common group in Tonkin Gulf and the next one belonged to dinoflagellates.

Since the synthesis of phytoplankton studies in Tonkin Gulf and adjacent areas from 1959 to 2009, Nguyen Hoang Minh et al. (2011) reported that a total of 449 species, 100 genera belonging to 4 classes had been found [10]. It is obvious that the number of species found in dry season -2003 and rainy season -2004 in the western of Tonkin Gulf was less diverse and occupied approximately $62 \%$. However, the new findings in the later study is that we have recorded some new taxa added for the area mainly belonging to dinoflagellates (such as Alexandrium genus and the species belonging to, and some species of Prorocentrum etc.) even though the scale of spatial and temporal sampling in this study was limited in comparing with the previous studies. The reason of this maybe caused by: we have used the plankton net with mesh size of $20 \mu \mathrm{m}$ while the ones used in the past studies were bigger with mesh size from $80-100 \mu \mathrm{m}$. The majority taxa added in this study have size of cell were smaller than $50 \mu \mathrm{m}$. Besides, the using fluorescence microscope for identifying dinoflagellate species basing on thecal plate arrangement was a significant enhancement of identification of this group.

The most diversely genera presented in Tonkin Gulf during the surveys in 2003 and 2004 in turn as followings: Ceratium 25 species, Protoperidinium (23 species), Coscinodiscus and Chaetoceros (17 species for each), Rhizosolenia (15 species), Dinophysis (13 species), Alexandrium and Gonyaulax (9 species for each), Pleurosigma and Prorocentrum (8 species for each). The number of species in remains ranged from 1 to 7 species, mainly 1 or 2 species for each genus.

There were 26 species, 10 genera belonging to potentially harmful microalgae group found in the studied area. Among them, the genus Alexandrium was the most diverse in species, including 9 species, the followings were Dinophysis (5 species), 4 genera Pseudonitzschia, Trichodesmium, Prorocentrum and Gonyaulax (2 species for each) and the remains such as Protoceratium, Lingulodinium, Ceratium, Protoperi-dinium found only 1 species for each genus. 


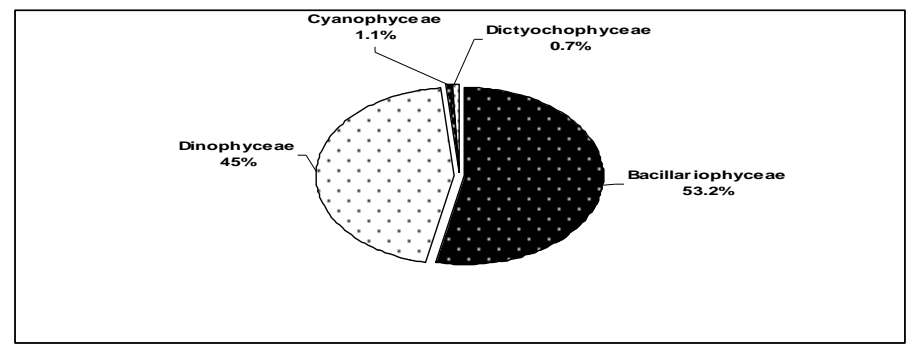

Figure 3: Percentage of phytoplankton groups in the western of Tonkin Gulf in October 2003 \& August 2004

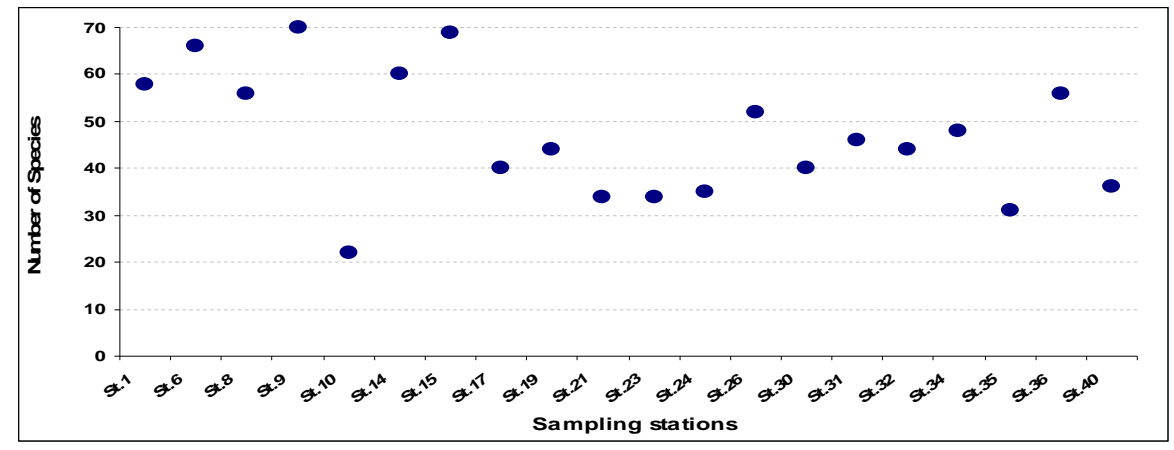

Figure 4: Distribution of species number in Tonkin Gulf in dry season - 2003

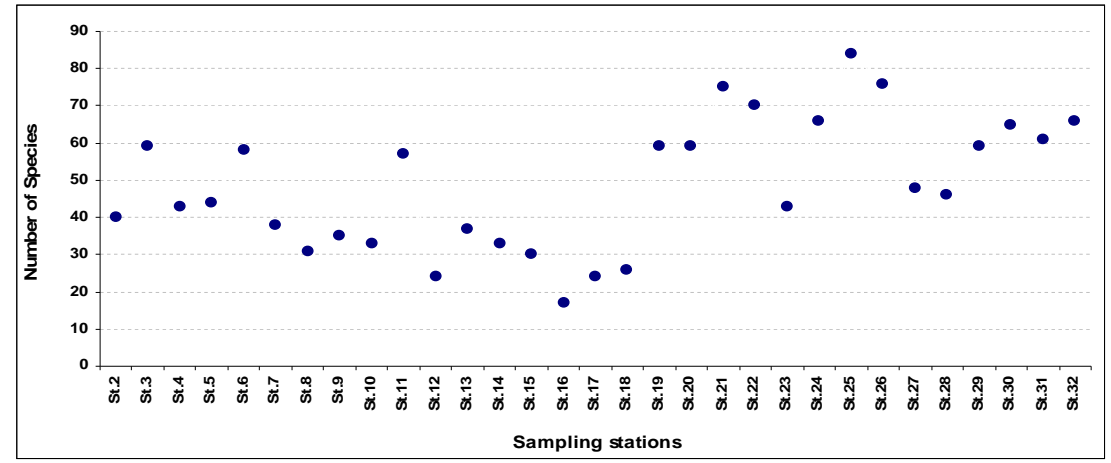

Figure 5: Distribution of species number in Tonkin Gulf in rainy season - 2004

The analyzing results of net haul samples in Tonkin Gulf in dry and rainy seasons showed that the number of species varied by stations and sampling time (Figs. 4, 5). In dry season, the number of species ranged from 30 to 70 species. It can be divided into three categories of species: $<30$ (1 station), 30 $\div 50$ (11 stations) and $50 \div 70$ (8 stations). In rainy season, the species number ranged from 17 to 84 species and could be divided into 4 levels: <30 (4 stations); $30 \div 50$ (12 stations); $50 \div 70$ (13 stations) and >70 (3 stations). It is 
obvious that the diversity of phytoplankton in dry season was more diversely than that in rainy one in the studied area. There were the different trends of species distribution between two surveys in Tonkin Gulf as followings: In dry season, except station 10 found only 22 species, the number of species in the upper area of the gulf was higher than that in the lower area with $50 \div 70 \& 30 \div 50$ respectively (except stations $26 \& 36$ found in turn 52 $\& 56$ species). The trend of species distribution in the studied area in rainy season was opposite to dry one. It means that the number of species in the lower area was more diversely than the upper (Fig. 5).

The diversity index (Shannon-Weaver or $\mathrm{H}^{\prime}$ index) of phytoplankton in the study area ranged seasonally. In dry season, $\mathrm{H}^{\prime}$ index of varied from 1.5 to less than 5.0, but the main values of $\mathrm{H}^{\prime}$ were in between 2.5 and 4.5 (Fig. 6). In rainy season, this index varied more widely than those in dry season, ranged from 0.3 to 5.4. However, the $\mathrm{H}^{\prime}$ values concentrated from 1.0 to 5.0 (Fig. 7).

It suggested that the diversity of species in the upper area of the gulf in August, a typical time of rainy season in the North Viet Nam, had been affected strong by the river discharge from several big rivers such as the Red, Thai Binh, Van Uc and Ma rivers, etc. By vertically, the diversity index of phytoplankton at the $10 \mathrm{~m} \& 20 \mathrm{~m}$ depths of spatial stations are usually higher than that in the surface ones (Figs. 6,7). The phytoplankton cell density of surface layer is usually higher than in the deeper that may be the one of main reasons causing this variation. There were not much different about diversity index among the sampling times at the same temporal sampling station. The variation trend of this index is similar to the spatial stations (Figs. 8, 9, 10). The changing of $\mathrm{H}^{\prime}$ index at different layers during temporal observation were more clearly at the near-shore area such as stns. $1,2,3$ in rainy season (Figs. 9, 10) than those at the off-shore area (stations 8, 22) in dry season (Fig. 8). It suggested that the stratification in near-shore area was strongly, especially in rainy season.

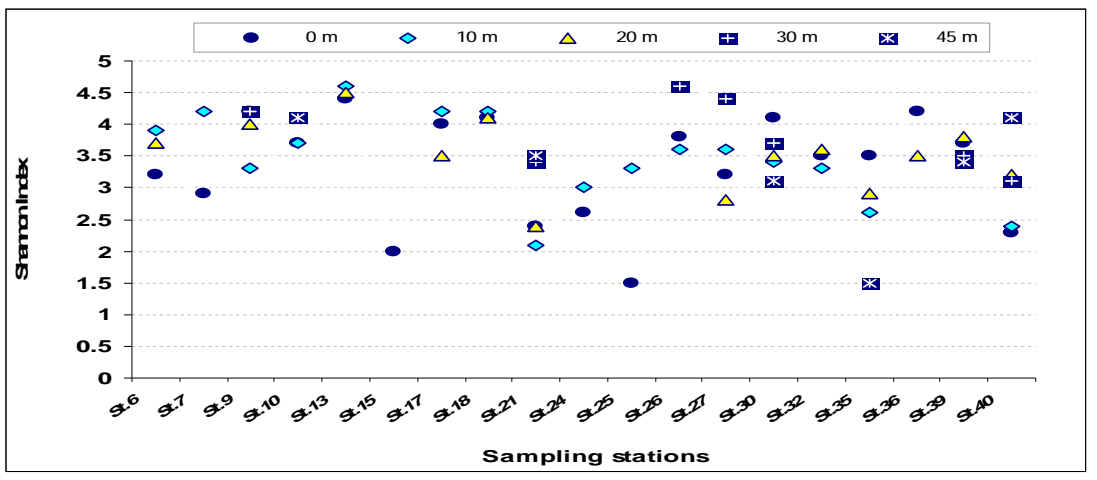

Figure 6: $\mathrm{H}^{\prime}$ index at the spatial sampling stations in dry season - 2003 


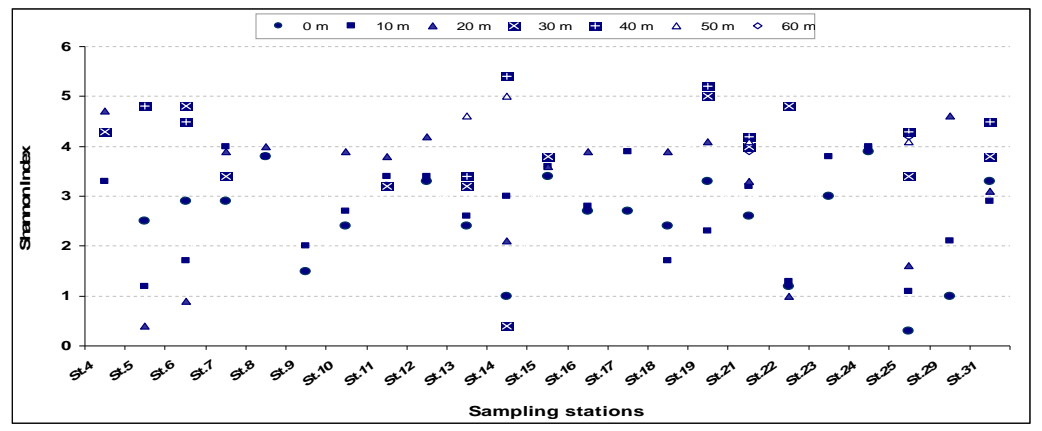

Figure 7: H' index at different depths of spatial stations in rainy season - 2004
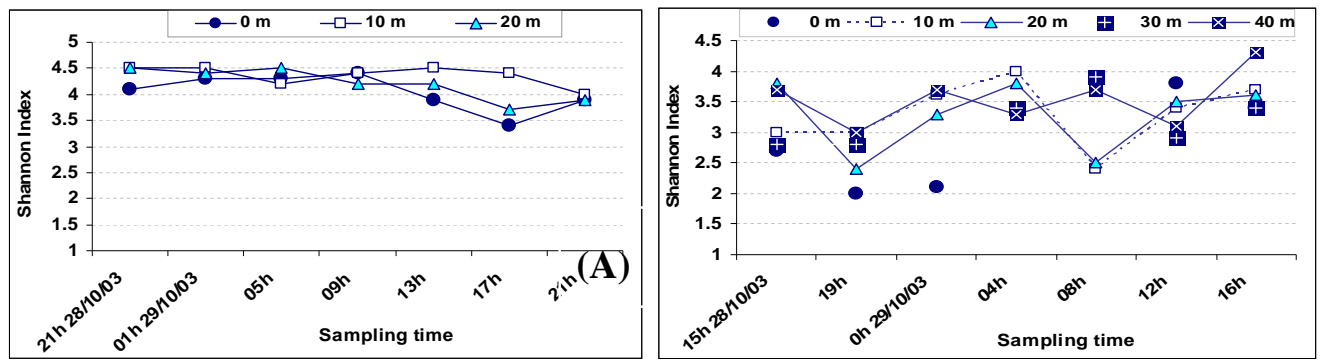

(B)

Figure 8: $H^{\prime}$ index at the temporal sampling stations $8(\mathbf{A})$ and $22(\mathbf{B})$ in dry season
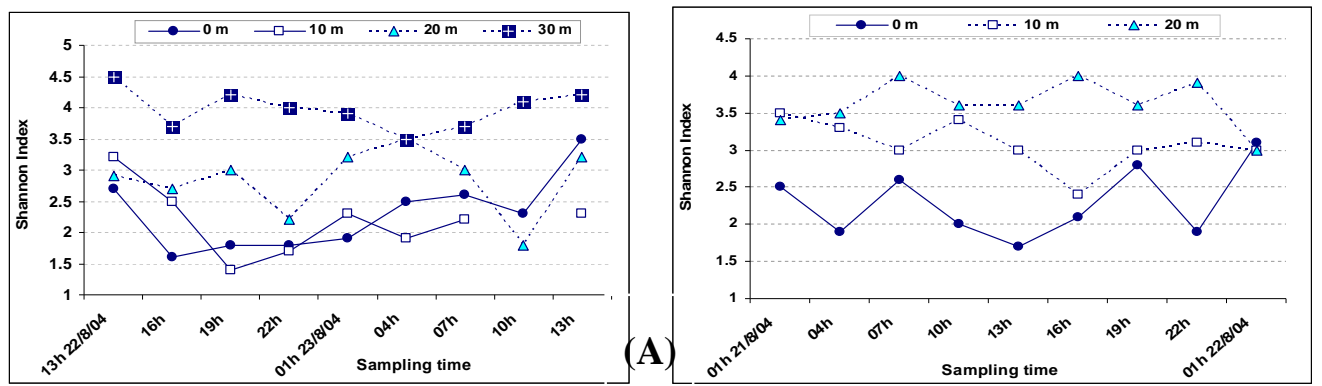

(B)

Figure 9: $\mathrm{H}^{\prime}$ index at the day-night sampling stations $1(\mathbf{A}) \& 2(\mathbf{B})$ in rainy season

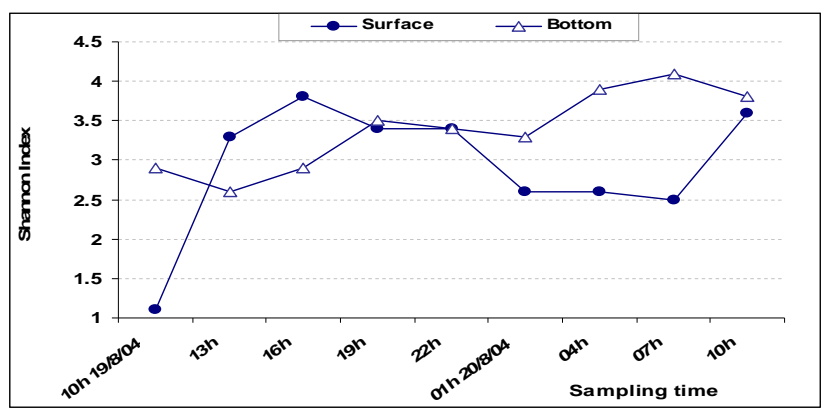

Figure 10: H' index at the temporal station 3 in rainy season - 2004 


\section{Distribution of phytoplankton density in the Tonkin Gulf}

\subsection{Spatial distribution}

In generally, the cell densities of phytoplankton at the sampling sites were less than $5 \times 10^{3}$ cell. $1^{-1}$. The cell density in rainy season was higher than that in dry one. The higher density values were recorded mainly at the near-shore (stationns 15, 24, 25 in dry and 4, 7, $22 \& 25$ in rainy season). According to Nguyen Hoang Minh et al. (2011), the density of phytoplankton in Tonkin Gulf varied from 667 to $663,466,000$ cell. $^{-3}$ and 5,486,000 cell. $\mathrm{m}^{-3}$ in average [10]. It is obvious that the density recorded in dry and rainy seasons in the western of Tonkin Gulf was equivalent with the previous studies.

The stratification of cell density in depths was more clearly with the higher density found in the surface layer. The variation of density in depth happened more strongly in rainy season than those in dry one in the spatial stations. The density variations during day-night at the temporal sampling stations in dry season were showed in Fig.13, and in rainy season (Figs. 14, 15). Among them, the distribution of cells at the $10 \mathrm{~m}, 20 \mathrm{~m} \& 30 \mathrm{~m}$ depths are usually higher than those at the surface layers in rainy season. It suggested that the water stratification at the near-shore area (stns. 1,2,3) happened strongly during this period might cause the density fluctuation in depth.

There were the differences of dominant species between two sampling times. In dry season, the most abundant species belonged to Thalassionema frauenfeldii that dominated in the central near shore area of the Gulf (stations 15, 21, 22, 24, 25 \& 32) with maximum

density about $1.6 \times 10^{4}$ cell. $1^{-1}$ at station 15 . This species had been also reported as one of the most abundant species in October 1960 [15].

In rainy season, there were several species that dominated locally in the studied area. The most widely species was Trichodesmium erythraeum that dominated at the offshore sampling stations from the north to south with highest density of $10^{4} \mathrm{cell}^{-1^{-1}}$. The next was Pseudo-nitzschia spp. that dominated in the southern area of the Gulf including stns. $22,25,26,29 \& 33$ with maximum density of $5 \times 10^{4}$ cell. $1^{-1}$. According to Chu Van Thuoc et al. (2009), there were two peaks of Pseudo-nitzschia density found in January 2003 and October 2002 in Nghe An-Ha Tinh coastal waters [4]. This genus dominated also in October 2004 with highest density up to $10^{5}$ cell. $1^{-1}$ beside the peak of density recorded in January and April 2005 in the Red river mouth [3]. It revealed that October was one of the preferable times for Pseudo-nitzschia growth in Tonkin Gulf. Two other dominants included Thalassionema frauenfeldii and Chaetoceros spp. had been also found at rather high density in the southern area. The first one occurred at stations $22,32 \& 33$ with maximum density ca. $10^{3}$ cell. $1^{-1}$, the later was at station 22 with density of $2 \times 10^{3}$ cell. $1^{-1}$. Some species such as Bacteriastrum hyalinum, Chaetoceros curvisetus, Ch. lorenzianus, Pseudo-nitzschia spp., Thalassionema frauenfeldii, Th. nitzschoides, Thalassiosira subtilis had been reported as the dominant species in the year in Tonkin Gulf [10]. 


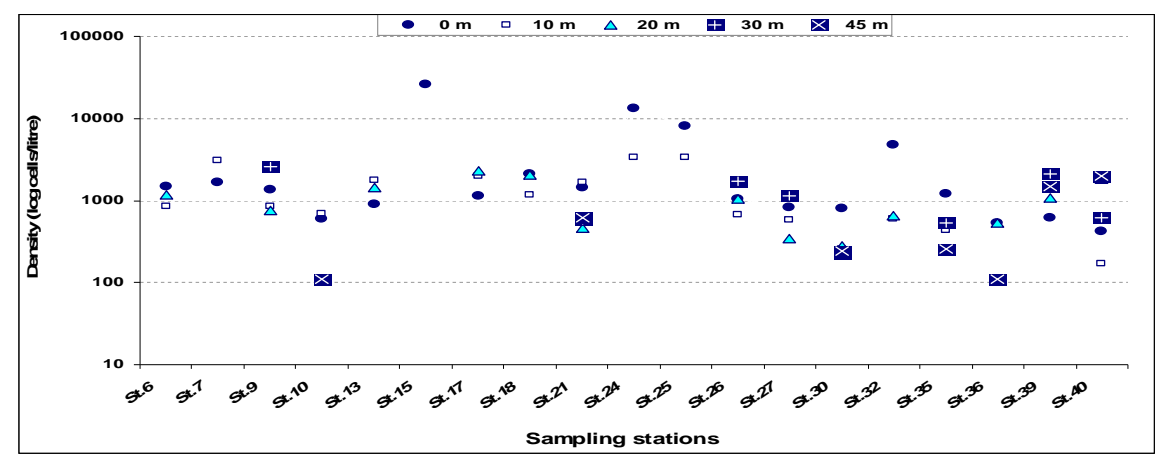

Figure 11: Distribution of cell density at the spatial stations in dry season - 2003

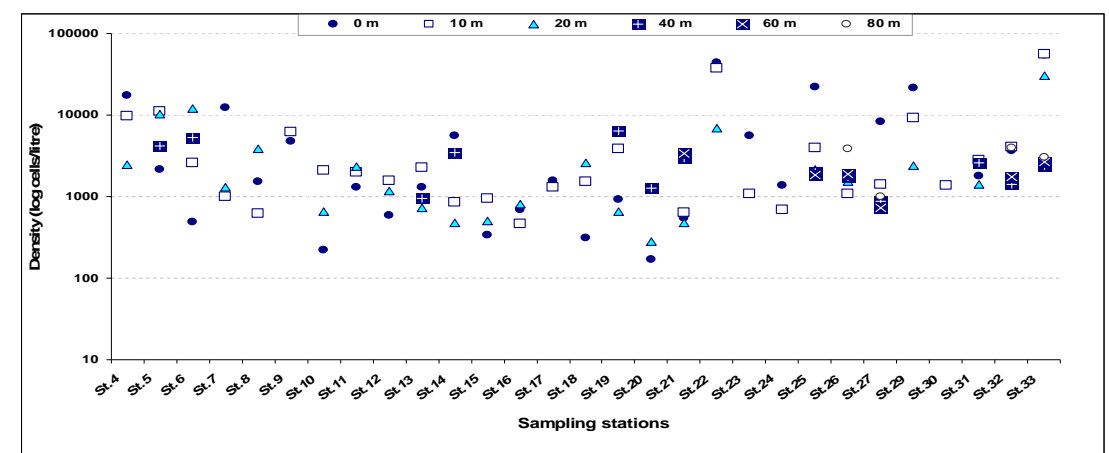

Figure 12: Distribution of cell density at the spatial stations in rainy season - 2004

\subsection{Temporal distribution}

The variation of phytoplankton density during day-night was presented in Figs. 13, 14,15 . In generally, the distribution of cell density at the temporal sampling stations was mainly less than $2 \times 10^{3}$ cell. $1^{-1}$. Normally, the density in the surface layers is usually increase during the day time and decrease in night time. However, in many cases, the density in the lower layers such as $10 \mathrm{~m}, 20 \mathrm{~m}$ depths was higher than that in the surface layer at the same time. The fluctuation of density by time at the stations located near river mouths (stations 1,2) happened stronger than the ones those were less affected from rivers (station 3 for instance). 

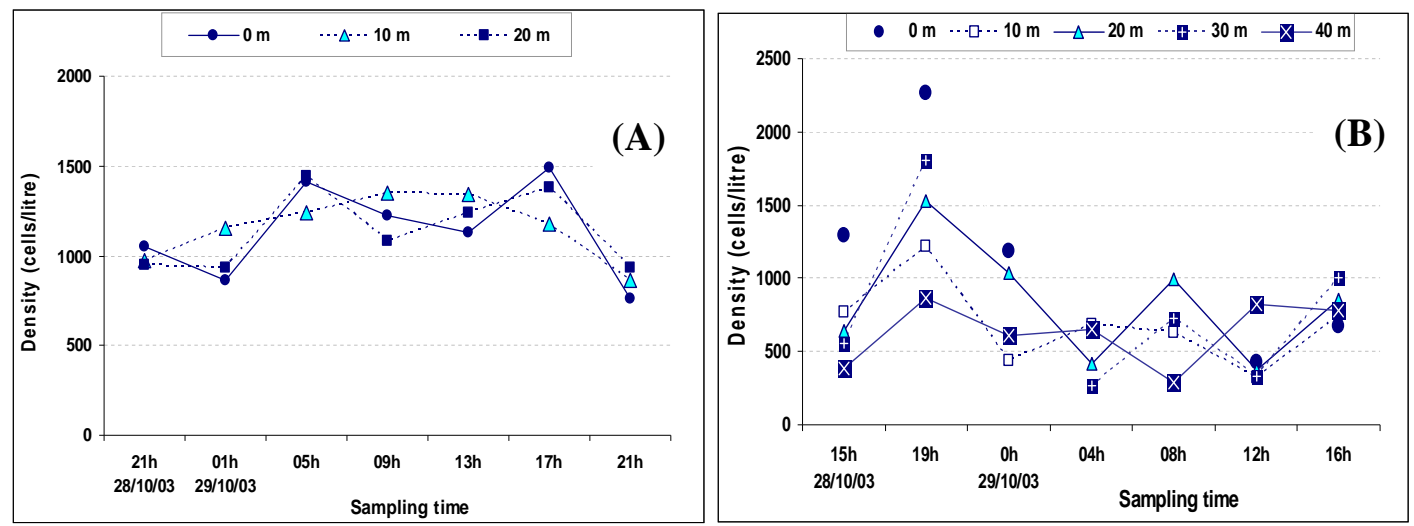

Figure 13: Distribution of cell density at the temporal sampling stations 8 (A) and 22 (B) in dry season
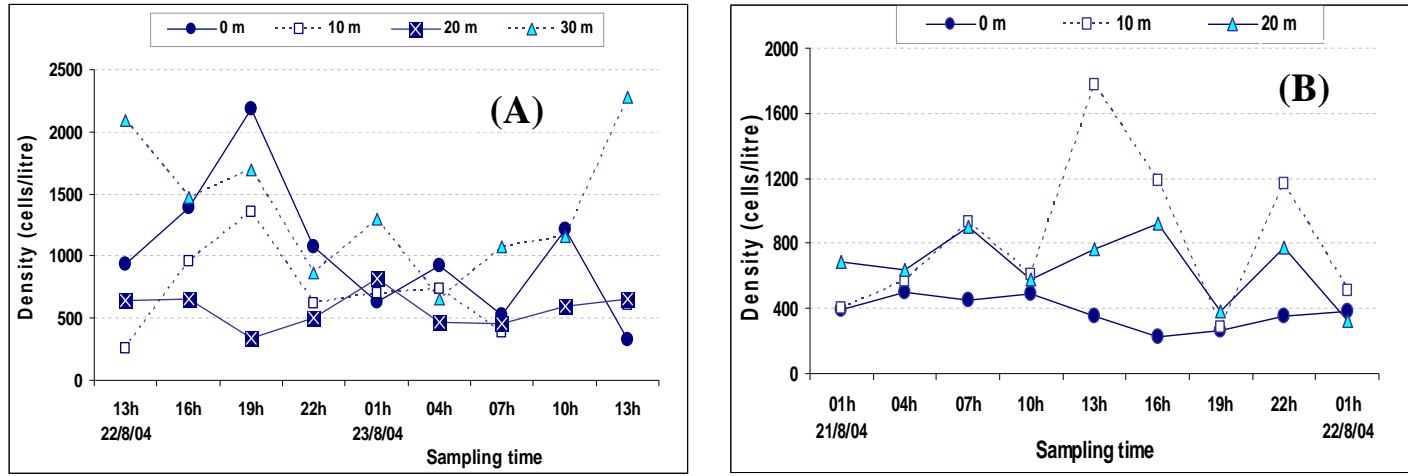

Figure 14: Distribution of cell density at the temporal sampling stations 1 (A) and 2 (B) in rainy season

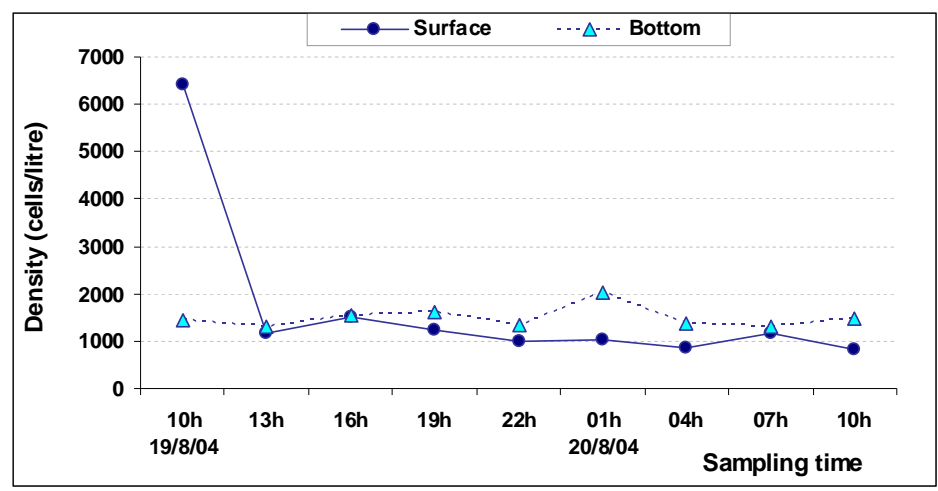

Figure 15: Distribution of cell density at the temporal sampling station 3 in rainy season

\section{Distribution of potentially harmful phytoplankton in the western of Tonkin Gulf}


Table 1: Present frequency of potentially harmful algae in the western of Tonkin Gulf

\begin{tabular}{|c|c|c|c|}
\hline \multirow[b]{2}{*}{ No. } & \multirow[b]{2}{*}{ Taxa } & \multicolumn{2}{|c|}{ Present frequency (\%) in the qualitative samples } \\
\hline & & $\begin{array}{c}\text { Dry season (Oct. } \\
2003)\end{array}$ & Rainy season (Aug. 2004) \\
\hline 1 & Pseudo-nitzschia spp. & 66.7 & 25.0 \\
\hline 2 & Alexandrium affine & Absent & 9.4 \\
\hline 3 & Alexandrium cf. acatenella & Absent & 3.1 \\
\hline 4 & Alexandrium globosum & 4.8 & Absent \\
\hline 5 & Alexandrium fraterculus & Absent & 9.4 \\
\hline 6 & Alexandrium leei & Absent & 21.9 \\
\hline 7 & Alexandrium insuetum & Absent & 21.9 \\
\hline 8 & Alexandrium pseudogonyaulax & Absent & 3.1 \\
\hline 9 & Alexandrium tamiyavanichii & 4.8 & 34.4 \\
\hline 10 & Alexandrium sp. & 4.8 & 18.8 \\
\hline 11 & Dinophysis caudata & 28.6 & 68.8 \\
\hline 12 & Dinophysis miles & 90.5 & 75.0 \\
\hline 13 & Dinophysis sp. (cf. fortii) & Absent & 12.5 \\
\hline 14 & Dinophysis rotundata & 4.8 & 43.8 \\
\hline 15 & Dinophysis mitra & Absent & 28.1 \\
\hline 16 & Ceratium fusus & 47.6 & 90.6 \\
\hline 17 & Gonyaulax polygramma & 9.5 & 65.6 \\
\hline 18 & Lingulodinium polyedrum & 4.8 & 6.3 \\
\hline 19 & Prorocentrum micans & 9.5 & 28.1 \\
\hline 20 & Prorocentrum cf. rhathymum & 14.3 & 12.5 \\
\hline 21 & Protoceratium reticulatum & Absent & 18.8 \\
\hline 22 & Protoperidinium crassipes & Absent & 65.6 \\
\hline 23 & Dictyocha fibula & 23.8 & 56.3 \\
\hline 24 & Trichodesmium spp. & 81.0 & 62.5 \\
\hline
\end{tabular}

The analyzing results of net samples collected during two cruises in the studied area showed that the number of potentially harmful species in rainy season was more diverse and presented at higher frequency in comparing with those in dry season with $23 \& 14$ species respectively. Among them, Alexandrium was the most diversely genus in both cruises, especially in rainy season. The list of species and their present frequency are showed in Table 1.

Dinophysis miles was the most common species at the sampling sites during the survey in dry season 2003, the followings were Trichodesmium spp. (cyanobacteria), Pseudo-nitzschia spp. (diatoms) and Ceratium fusus. In case of Dinophysis miles that had been reported as the most common dinoflagellates distributed widely in Tonkin Gulf in 
Oct. 1960, though its density was not high [15]. In rainy season 2004, the most popular species in the studied area belonged to Ceratium fusus, Dinophysis miles, D. caudata, Protoperidinium crassipes, Gonyaulax polygramma, Trichodesmium spp. and Dictyocha fibula with their present frequency varied from 60 to 90 percent (Table 1). Regarding to Alexandrium genus, the A. tamiyavanichii was the most widely distributed species, the followings were A. leei, A. isuetum and Alexandrium sp.

Regard to the distribution of cell density of potentially harmful species, except some species belonging to Pseudo-nitzschia and Trichodesmium genera occurred at rather high density that had been mentioned above. The remains found only in net samples and in many cases completely absented in the samples collected by Niskin.

\section{CONCLUSION}

During the investigations in dry season (Oct. 2003) and rainy season (Aug. 2004), a total of 278 species, 81 genera, 4 classes of microalgae had been recorded in the western of Tonkin Gulf with the majority belonging to diatoms (51 genera, 148 species, occupied $53.2 \%$ ) and dinoflagellates (28 genera, 125 species, $45 \%$ ).

There were 26 potentially harmful species found in the studied area with the most diverse belonged to dinoflagellates such as Alexandrium (9 species), Dinophysis (5 species). Dinophysis miles, Trichodesmium spp., Ceratium fusus were the most common species in both dry and rainy seasons while Pseudo-nitzschia spp. were more popular in dry season and Dinophysis caudata, Protoperidinium crassipes, Gonyaulax polygramma and Dictyocha fibula in rainy season.

Diversity index ( $\mathrm{H}^{\prime}$ index) of phytoplankton in the study area ranged seasonally. In dry season, this index varied from 1.5 to less than 5.0, mainly in between 2.5 and 4.5. In

rainy season, this index varied more widely than those in dry season, it ranged from 0.3 to 5.4, mainly from 1.0 to 5.0.

The total cell density of phytoplankton decreased from the coastal to off-shore areas with the higher values recorded mainly at the near-shore area. The density in rainy season was higher and fluctuated more strongly than those in dry season. For the density of potentially harmful species, except Pseudo-nitzschia spp., Trichodesmium spp. occurred with the densities ranged from a few thousands to more than ten thousands cells per litre. The species remains found only in net samples, in many cases completely absented in the samples collected by Niskin bottle. 
Acknowledgment: This study was funded by the national project coded KC0917.01. We thank to the colleagues of IMER for their assistance for the sampling carried out in Tonkin Gulf.

\section{REFERENCES}

1. Abe H. T., 1967. The armoured dinoflagellata: II. Prorocentridae and Dino-physidae (B) - Dinophysis and its allied genera. Publ, Seto Mar. Biol. Lab., XV(1): 37 - 78.

2. Balech E. 1995. The genus Alexandrium Halim (Dinoflagellata). Sherkin Island Marine Station, Sherkin Island, Co. Cork, Ireland.

3. Chu Van Thuoc, 2006. The synthesis report of the national project "Harmful microalgae investigation in the coastal concentrated fisheries culture areas of Vietnam and propose the measurements for preventing and mitigating their effects" (KC.09.19). Preserved in IMER and NACESTI, MOST (in Vietnamese).

4. Chu Van Thuoc, Nguyen Thi Minh Huyen, Nguyen Thi Thu, 2009. Distribution of marine microalgae with emphasize on harmful species in the high potential area for mariculture in Nghe An - Ha Tinh coastal waters, Central Viet Nam. Journal of Marine Science and Technology (1) 2009: 169-184.

5. Fukuyo Y., Takano H., Chihara M. \& Matsuoka K., 1990. Red tide organisms in Japan - An illustrated taxonomic guide. Uchida Rokakuho, Tokyo, Japan.

6. Larsen J. \& Moestrup $\varnothing$., 1992. Potential toxic phytoplankton -2. Genus Dinophysis (Dinophyceae). ICES Identification Leaflets for Plankton.

7. Larsen J. and Nguyen N. L. (Eds.), 2004. Potentially toxic microalgae of Vietnamese waters, Opera Botanica 140, Copenhagen.

8. Nguyen Tien Canh, 1977. Species composition, distribution and density variation of phytoplankton in the western coastal water of Tonkin Gulf. Synthesis scientific report preserved in the Research Institute for Marine Fishery (in Vietnamese).

9. Nguyen The Tuong, 2006. General investigation on natural conditions, resources and environment of Tonkin Gulf (Project coded KC-09-17). In the Collection of main results of the national program on basic investigation and application study of marine technology. Tome III: 426-536. MOST, Hanoi (in Vietnamese). 
10. Nguyen Hoang Minh, Vu Minh Hao, Nguyen Van Quang, 2011. Phytoplankton in the western area of Tonkin Gulf and adjacent areas. Journal of Marine Science and Technology, 11(4): 57-73 (in Vietnamese).

11. Taylor F. J. R., 1976. Dinoflagellates from the International Indian Ocean Expedition - A report on material collected by the R.V."Anton Bruun" 1963 - 1964, Stuttgart.

12. Tomas C. R., 1997. Identifying Marine Phytoplankton. Academic Press Harcourt Brace \& Company.

13. Truong Ngoc An, 1978. Phytoplankton in the coastal waters of Hai Phong - Quang Ninh. Synthesis scientific report preserved in IMER (in Vietnamese).

14. Truong Ngoc An, 1993. Taxonomy of Marine Diatoms in Vietnam. Technical and Scientific Publishing House, Hanoi (in Vietnamese).

15. Viet Nam-China Joint Survey Team, 1965. Synthesis scientific report on "Marine general investigation in the Tonkin Gulf". Part IV: Plankton. Preserved in IMER (in Vietnamese).

\section{MỘT SỐ DÃ̃N LIỆU MỚI VỀ PHÂN BỐ THỤC VẠT PHÙ DU Ở TÂY VỊNH BẮC Bộ}

\section{CHU VĂN THUỘC, NGUYễN TH!̣ MINH HUYỀn, PHẠM THẾ THƯ, LÊ THANH TÙNG}

Tóm tắt: Bài báo này trình bày một số dẫn liệu nghiên cúu mới về phân bố quần xã thực vật phù du ở phía tây Vịnh Bắc Bộ có được tù hai đọt khảo sát vào mùa khô (tháng 10/2003) và mùa mua (tháng 8/2004). Các mẫu TVPD được thu thập ở 21 trạm (tháng 10/2003) và 32 trạm (tháng 8/2004) trải đều trên toàn khu vục phía tây Vịnh, tại các độ sâu khác nhau, với khoảng cách tù 10-20 m tùy theo trạm. Trong đó, có 2 trạm thu mẫu liên tục ngày đêm trong mùa khô và 3 trạm trong mùa mua, tại các trạm này cú 3-4 giờ thu mẫu một lần. Tổng số có 278 loài, 81 chi và 4 lớp tảo đã được phát hiện ở vùng nghiên cúu, phần lớn thuộc về tảo Silic (51 chi, 148 loài, chiếm 53,2\%), tiếp đó là tảo Giáp (28 chi, 125 loài - 45\%). Khoảng 26 loài tảo có khả năng gây hại đã được ghi nhận ở vùng nghiên cúu, trong đó đa dạng nhất là các chi Alexandrium (9 loài), Dinophysis (5 loài). Chỉ số đa dạng loài $H^{\prime}$ của TVPD ở vùng nghiên cứu dao động tù 1,5 đến 5,0 (mùa khô) và 0,3 đến 5,4 (mùa mura). Mật độ tế bào TVPD biến động theo mặt rộng và theo cột nước. Nhìn chung,mật độ tế bào giảm dần tì bờ ra khơi, tù mặt xuống đáy nhung tại các trạm thu mẫu ngày đêm ở ven bò̀ tây bắc Vịnh có xu thế ngược lại. Mật độ tế bào trong mùa mưa cao hơn và biến động mạnh hơn mùa khô.

Ngày nhận bài: 28 - 10 - 2011

Người nhận xét: PGS. TS. Đỗ Công Thung 